\title{
FROM CRITICAL THEORY TO PRAGMATISM
}

\section{Andrew Feenberg}

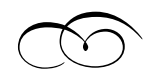

ver the course of more than two decades, during which he has published an impressive number of books and essays, Andrew Feenberg has established himself as an important representative of a new generation of Critical Theorists. ${ }^{1}$ Consistently insightful and articulate, he has developed a trenchant critique of technological culture that has taken as its point of departure the humanistic Marxism of his mentor, Herbert Marcuse. In his recent book Questioning Technology, he presents what is arguably his most successful attempt to construct a major revision of the critique of technology advanced by Marcuse and other first-generation Critical Theorists and the succeeding generation, including Habermas. At one level his work can be read as fulfilling a promise that Marcuse offered but left vague. At a deeper level, however, Questioning Technology can be viewed as a move away from some of the core ideas of Marcuse and the earlier Critical Theorists.

As a student of Marcuse, Feenberg might be thought to belong to the second generation of Critical Theory. Following Joel Anderson's 
excellent essay on the history of the Frankfurt School, however, our best option is to place Feenberg's work squarely within Critical Theory's third generation. The first generation was interested in emancipation from instrumental rationality as ideology by means of reflective social science. The second generation focused on the development of communicational tools to promote moral development and respect for constitutionality, as well as to overcome social pathologies such as extreme nationalism, xenophobia, and the colonization of the lifeworld by technoscientific rationality. The third generation, whose experiences were formed by the events of 1968, has abandoned the essentialist and substantialist views of its forebears in favor of positions that are more thoroughly functionalist and constructivist. This generation has turned its attention to problems of pluralism, multiculturalism, and globalization, and has tended to view problems of technoscience not as separate from, but as a part of social life. ${ }^{2}$

To those familiar with the central ideas of American Pragmatism, some of the planks in Feenberg's platform will therefore appear remarkably familiar. More specifically, Feenberg's revisions of Marcuse have the interesting effect of moving his critique noticeably in the direction of the instrumental version of Pragmatism that was developed in the first half of the twentieth century by Dewey. It is perhaps not surprising that this should have occurred, given attempts by Habermas and Apel, second-generation Critical Theorists, to appropriate the insights of Peirce, and the influential studies of Mead by Hans Joas, who has influenced third-generation Critical Theorists.

But this similarity between the Feenberg of Questioning Technology and Dewey's Pragmatic critique of technology, I suggest, is all the more significant given the fact that Feenberg has not given his readers much evidence that he is aware of this situation. In Questioning Technology, for example, he devotes a total of about a half page to Dewey, in which he discusses Dewey's treatment of democratic deliberation and then dismisses him as having exhibited an "uncritical confidence in science and technology." ${ }^{3}$ Ten pages later, however, he reminds us that Dewey foresaw how "the dispersion of the technological citizenry" and other factors, including a "media-dominated public 
process," would account "for the passivity of a society which has not yet grasped how profoundly affected it is by technology" (QT, 146).

The apparent conflict between these two assessments may in fact not be so great as it at first appears. Although Dewey did have a measure of confidence in science and technology, or what is now frequently termed "technoscience," his attempts to present a democratized critique of technology are remarkably similar to those that Feenberg himself is now advancing. For those who are sympathetic to the programs of the American Pragmatists, as I am, what I have termed "Feenberg's Progress" is therefore a matter to be applauded.

It is probably best to begin by looking at Feenberg's history of the philosophical critique of technology. Presenting "before and after" snapshots in the preface to Questioning Technology, he describes what he views as "a fateful change in our understanding of technology" (QT, vii). What is this change? Put simply, before philosophical critiques of technology began to exhibit functionalist accounts of the current democratization of the technical sphere, they were almost universally essentialist. On the cultural and political right, there were the romantics: the John Ruskins and the Heideggers who viewed technology as the root cause of all that was dehumanizing. On the cultural and political left there were socialists and progressives who tended to an uncritical acceptance of everything that came off the engineers' drawing boards. But it should not be thought that these opposing and frequently conflicting camps had nothing in common. As Feenberg views matters, they "all agreed that technology was an autonomous force separate from society, a kind of second nature impinging on social life from the alien realm of reason in which science too finds its source" (QT, vii).

It is worth noting that although first-generation Critical Theorists Horkheimer and Adorno were constructivists with respect to "the social world," they were essentialists with respect to technology (which they placed over against the social). Marcuse shared their view in a slightly weaker form: although he never worked out the details, his view was apparently that political reform was a necessary, but not sufficient, condition for the reform of technology. ${ }^{4}$ Moreover, it will 
hardly be news even to casual readers of Habermas that his early work advanced a version of technological essentialism. He reduced technoscience to "instrumental rationality" and fact-gathering, a view he has since neither rejected nor revised.

The situation has since changed. Conditions of emerging and expanding democratization have led critics to question essentialism, let alone the more extreme view, advanced by Jacques Ellul and others, that the essence of technology is nefarious through and through. For Ellul, technology is a thing: a debilitating, all-consuming, autonomous force. As a response to these new conditions, Feenberg thinks, it now seems important to move technology from the "autonomous/ other" column into a column that might be labeled "our social matrix." Put another way, the idea of the essentialists that technology occupies a location separate from the places where meaning and value are constructed has given way to the notion that meaning and value are also constructed in the context of technoscientific decisionmaking.

Feenberg's response to this changed situation has been to issue a manifesto. "The time has therefore come," he writes, "for an antiessentialist philosophy of technology" (QT, viii). His book is dedicated to working through what he thinks will be the characteristics of this new anti-essentialist philosophy.

The new anti-essentialism will in his view be an invigorated constructivism that allows for the possibility of difference where there was only the monolithic "technology as thing," and that therefore takes into account, as he puts it, the "social and historical specificity of technological systems, the relativity of technical design and use to the culture and strategies of a variety of technical actors" (QT, x). As I have already indicated, Horkheimer and Adorno were also constructivists. But their constructivism was limited to what they regarded as the social world-a world they perceived as existing over against the world of technoscience, in which instrumental rationality held sway, and also over against nature, which was treated as just "given." 5 
What does this mean in practice? For one thing, it means that Feenberg has adopted a more comprehensive and explicit constructivist position, which holds that technology is neither determining nor neutral. ${ }^{6}$ Feenberg indicates that he is following the suggestion of Don Ihde that "technology is only what it is in some use-context" (QT, 213).7

But of course this notion is Instrumentalist as well as constructivist, and it has a fairly long pedigree. It recalls McLuhan's insight that media are the extensions of "man," and also what Melvin Kranzberg was fond of calling "Kranzberg's First Law," namely that technology is neither positive, nor negative, nor neutral. Does this mean that the methods and devices of technology are vectorless, that they do not possess momentum? Of course not. The point asserted by these Instrumentalists is just that even though technological artifacts often possess a high degree of momentum, even to the degree that it is sometimes almost impossible to overcome their motion, there is nevertheless a relation of feedback between the selection of tools and methods and the influence that those tools and methods have over our lives. As McLuhan put it, we shape our tools; thereafter they shape us.

It is also worth noting that this type of Instrumentalism-constructivism had already been well articulated long before it resurfaced during the 1960 s in the work of media theorist McLuhan and historian Kranzberg. One version, for example, was developed at the end of the nineteenth century and the beginning of the twentieth by Dewey. The very name he gave to his version of Pragmatism might well have served as a clue to sharp-eared philosophers of technology that they might find something of interest in his work: he called his view Instrumentalism. Given the long history of Instrumentalism-constructivism as an approach to the philosophy of technology, therefore, Feenberg's manifesto- that "the time has therefore come for an antiessentialist philosophy of technology"-has an odd (but welcome) ring to the ears of this Pragmatist.

From the negative side, as part of his rejection of the technological determinism evident in Horkheimer and Adorno and lurking in 
Marcuse, as well as from the positive side, as a part of his emerging commitment to an invigorated constructivism that includes technoscience, Feenberg has argued that technology is not just a matter of the rational control of nature. Both the development and the impact of technologies are intrinsically social: "Technologies are not physical devices that can be extricated from contingent social values. The technical always already incorporates the social into its structure" (QT, 210).

He has further insisted, "This view undermines the customary reliance on efficiency as a criterion of technological development . . . [which] opens broad possibilities of change foreclosed by the usual understanding of technology." "If one reads this statement in the light of Horkheimer, Adorno, and Marcuse, then "efficiency" should probably be understood as "instrumental reason" or what Langdon Winner has called "straight-line instrumentalism," and "the usual understanding of technology" should probably be read as the views espoused by the first and second generations of Critical Theorists.

In short, Feenberg is attempting to replace the monolithic models of technology with a flexible one, which puts the decisions about its tools, methods, and techniques within the sphere of the normativeevaluative, or what some have called "the lifeworld." In his view technology is not something foreign to human life. It is not, as his predecessors thought, ideology by another name. It is not an unrestrained quest for efficiency nor the domination of nature.

What then is technology? It is a natural activity of human beings, a part of their attempt to secure transitory goods and improve the conditions of their lives, both as individuals and as groups. It is a method of decision-making in which means and ends are weighed against one another in a process of continual readjustment. It is complex, multifaceted, and, with the requisite amount of effort, even reversible. It is possible to speak of technological progress and regress as well. Given the factors that I have listed in this paragraph, it should be clear that Feenberg's break with the first-generation Critical Theorists is massive and dramatic. More important for present purposes, 
however, this paragraph also contains a pretty good representation of Dewey's Pragmatic technology.

As I have already indicated, anyone who finds Dewey's Pragmatist critique of technology attractive can only applaud Feenberg's Progress. The fact is that his position now resembles that of Dewey much more than that of his teacher, Marcuse. Already in the 1890 os Dewey was articulating a critique of technology that comprehends most of the elements I just listed. He continued to refine that critique right up until his death in 1952.

First, like Feenberg, he viewed technology as a multifaceted enterprise. For Dewey, this meant that technology was more or less interdefinable with inquiry in the broad sense of the term. Dewey rejected essentialism early on, calling for a functionalized understanding of what philosophers from the Greeks to the moderns had called essences. According to his functionalist view, the essence of an event, object, or institution amounts to those aspects which we ("we" in this instance meaning members of various publics or communities of inquiry) find of sufficient relevance to our own needs and interests that we select them to characterize that event, object, or institution.

Dewey claimed that essentialists tend to commit what he called "the philosophical fallacy," namely the taking of something that is the result of inquiry as if it had existed prior to that sequence of inquiry in precisely the form that the inquiry determined it to be. Dewey's philosophical fallacy is, of course, more or less what Alfred North Whitehead would later call "the fallacy of misplaced concreteness," which is in turn the very fallacy that Feenberg condemns in the closing pages of Questioning Technology. When technology is stripped of its values and social context, Feenberg writes, as sometimes occurs in engineering and management contexts, "technology emerges from this striptease as a pure instance of contrived causal interaction. To reduce technology to a device and the device to the laws of its operation is somehow obvious, but it is a typical fallacy of misplaced concreteness" (QT, 213).

Like Feenberg, but unlike Marcuse, Dewey refused to accept the explicit separation between facts and values the early Critical Theorists 
made to drive a wedge between technoscience as the rational gathering and deployment of facts and technoscience as a realm of meanings and values developed in the context of a lifeworld. For Dewey, as for Feenberg, technological decision-making is at each fork in the road precisely about which of many possible values will be secured.

For Dewey, moreover, decision-making in the spheres of technoscience is never a matter of starting from scratch. It operates against the backdrop of two sorts of assumptions: those things that are valued in fact and those things that are valued by experimental deliberation. For Dewey there are no pure, contextless facts ready to be gathered by activities of putatively value-free technosciences. Instead, it was Dewey's view that the technosciences operate in much the same way as do other areas of human inquiry: facts are always facts of a case, selected by individual human agents or groups of them, embodied at a particular time and place and carrying forward a particular history against a particular cultural backdrop. For Dewey and Feenberg, but not for the early Critical Theorists, there is no contextless technoscience.

Perhaps even more important, however, both Dewey and Feenberg honor the idea that means and ends are not isolated from one another, that in productive forms of technology neither means nor ends should be viewed as dominating the other. Feenberg's position is clear enough in his discussion of the ways in which various theories of technology have tended to treat this issue.

Deterministic theories, such as traditional Marxism, minimize our power to control technical development, but consider technical means to be neutral insofar as they merely fulfill natural needs. Substantivism shares determinist skepticism regarding human agency but denies the neutrality thesis. Ellul, for example, considers ends to be so implicated in the technical means employed to realize them that it makes no sense to distinguish means from ends. Critical theories, such as Marcuse and Foucault's left dystopianism, affirm human agency while rejecting the neutrality of technology. Means and ends are linked in systems subject to our ultimate control. This is the position defended here, although I work it out differently from Marcuse and Foucault. (QT, 9) 
Feenberg's difference with Foucault and Marcuse on this issue, as well as with what he calls the "common sense" view, seems to be as follows. For the common sense view, technology is neutral and thus available to serve values and ends that are formulated independently. In the views of Foucault and Marcuse, however, "choices are not at the level of a particular means but at the level of a whole means-ends systems" (QT, 7).

Feenberg's own view is similar to that of Dewey. He posits two dimensions of what he terms "technical objects." The first is their social meaning and the second is their cultural horizon. The point of the first dimension is that engineering goals hardly ever have the last word, even when successfully articulated. Although it may turn out to the disappointment of the engineers in question, social meanings, some of which are quite different from original engineering goals, also enter into the life of technical and technological objects. On this functionalist approach, straight-line instrumentalism gives way to the ramification of multiple possibilities. As Feenberg puts the matter, "Differences in the way social groups interpret and use technical objects are not merely extrinsic but make a difference in the nature of the objects themselves." 10 Dewey would, of course, have applauded this conclusion.

The second hermeneutic dimension, the cultural horizon, refers to cultural background assumptions. In the medieval period of the Latin West this involved a preoccupation with religious signs and symbols, and in our own milieu it involves rationalization. Apparently unaware that he is echoing remarks that Dewey made more than six decades ago, Feenberg has concluded that "technology is thus not merely a means to an end; technical design standards define major portions of the social environment" (QT, 97).

For Feenberg technological choices are made by "social alliances." Such alliances appear to be more or less what Dewey termed "publics" in his 1927 book, The Public and Its Problems. Here is Feenberg: "A wide variety of social groups count as actors in technical development. Businessmen, technicians, customers, politicians, bureaucrats are all involved to one degree or another. They meet in the design 
process where they wield their influence by proffering or withholding resources, assigning purposes to new devices, fitting them into prevailing technical arrangements to their own benefit, imposing new uses on existing technical means, and so on. The interests and worldview of the actors are expressed in the technologies they participate in designing" (QT, 10-11). Feenberg's invigorated constructivism holds that "technology is social in much the same way as are institutions” (QT, 11). In Feenberg's vision of a “deep” democratization of technology, his alternative to technocracy, the activities of such social alliances will be wedded to "electoral controls" on technical institutions.

As I have already indicated, this vision, and the detailed analysis that supports it, of increasing electoral control by overlapping networks of educated and informed publics over the various "social alliances" that contribute to technoscientific decision-making, is precisely what Dewey was arguing for in 1927 in The Public and Its Problems.

In that work Dewey was highly critical of technological determinism. "There are those who lay the blame for all the evils of our lives on steam, electricity and machinery. It is always convenient to have a devil as well as a savior to bear the responsibilities of humanity. In reality, the trouble springs rather from the ideas and absence of ideas in connection with which technological factors operate" (LW 2.323). Furthermore, he argued, "The instrumentality becomes a master and works fatally as if possessed of a will of its own-not because it has a will but because man has not" (LW 2.344).

Nor is this Feenberg's common sense view of technoscientific neutrality. For Dewey technoscientific artifacts teem with meanings, and this because such artifacts are the subjects of intent and desire, and intent and desire are inevitably social in nature. "Primarily," writes Dewey in 1925, "meaning is intent and intent is not personal in a private and exclusive sense. .. Secondarily, meaning is the acquisition of significance by things in their status in making possible and fulfilling shared cooperation" (LW 1.142). 
In 1939 Dewey specifically rejects the idea, still held by the Critical Theorists who were now working a stone's throw from his office at Columbia University, that "science is completely neutral and indifferent as to the ends and values which move men to act: that at most it only provides more efficient means for realization of ends that are and must be due to wants and desires completely independent of science" (LW 13.160). In other words, he rejects the split between a world of technoscientific facts and a lifeworld of meanings and values.

In 1946, in a revised introduction to The Public and Its Problems, Dewey puts this even more clearly.

Science, being a human construction, is as much subject to human use as any other technological development. But, unfortunately, "use" includes misuse and abuse. Holding science to be an entity by itself, as is done in most of the current distinctions between science as "pure" and "applied," and then blaming it for social evils, like those of economic maladjustment and destruction in war, with a view to subordinating it to moral ideals, is of no positive benefit. On the contrary, it distracts us from using our knowledge and our most competent methods of observation in the performance of the work they are able to do. This work is the promotion of effective foresight of the consequences of social policies and institutional arrangements. (LW 2.381)

How is this "promotion of effective foresight of the consequences of social policies and institutional arrangements" to be effected? Dewey cannot tell us directly, for his Instrumentalism incorporates perspectivism, contextualism, and fallibilism. But if he cannot do this, he can at least discuss the conditions under which such a "great community" will be possible. Such conditions include the free flow of information that is secured by means of experimental inquiry, among various overlapping publics which refine and express their interests in ways that make them amenable to discussion and compromise, and an educational system that is committed to the development among children of an intelligence of the type that prepares them for participation in a great community. Experts will be relied on not to 
make policy but to clarify for the various publics the various consequences of alternative scenarios. It will require that the tools and methods of technology be employed to assure a level of material and emotional security that is the precondition for such a community.

If the technological age can provide mankind with a firm and general basis of material security, it will be absorbed in a humane age. It will take its place as an instrumentality of shared and communicated experience. But without passage through a machine age, mankind's hold upon what is needful as the precondition of a free, flexible and many-colored life is so precarious and inequitable that competitive scramble for acquisition and frenzied use of the results of acquisition for purposes of excitation and display will be perpetuated. (LW 2.370-71)

These remarks anticipate Feenberg's claim that technology will be democratized not solely, or even primarily, through the legal system, but through greater "initiative and participation" that would result in the "creation of a new public sphere embracing the technical background of social life, and a new style of rationalization that internalizes unaccounted costs borne by 'nature.' "11

In sum, Feenberg follows Dewey on the following points: He has a) moved from an essentialist to a functionalist understanding of technology, b) developed a vigorous form of social constructivism, c) rejected a Heideggerian romanticism in favor of a naturalized technology, d) rejected the Critical Theorists' notion of technology as ideology, e) accepted the idea that the project of Enlightenment rationality is not as much of a threat as the Critical Theorists had imagined, f) proposed the idea that technical decisions are made within a network of competing factors in which one weighs various desired ends against one another, g) warned against the reification of the results of inquiry as if they had existed prior to inquiry (Dewey's "philosophic fallacy"), and h) recast technology in a way that crosses the line between artifacts and social relations. Did Dewey go beyond Feenberg? The short answer is yes. Dewey developed a philosophy of education and a deep analysis of "actor networks," which he termed "publics." He also developed a detailed philosophy of democracy, 
which is the centerpiece of his philosophy of technology. Taken with his theory of inquiry, and taken seriously, these aspects of Dewey's work provide the context for changing the way we talk about technology. My point in this chapter, however, has been to suggest that Feenberg's progress toward a Pragmatic reading of the philosophy of technology is the right move at the right time. 